\author{
E. E. Minkevich, \\ Senior Lecturer of General and Slavic Linguistics Department, \\ Odesa I. I. Mechnikov National University, \\ 24 / 26, Frantsuzky Blvd., Odesa, 65058, Ukraine, \\ movoznavstvo98@gmail.com
}

\title{
MODERN LOAN WORDS - NAMES OF PERSONS IN MODERN MASS MEDIA: SEMANTICS AND FUNCTIONS
}

\begin{abstract}
Summary
Loan words are a productive way to expand the lexicon of modern languages, names of people occupying an important place among neologisms, especially modern ones. This article deals with semantics and functioning of the newly borrowed words in mass media texts from 2018 till 2019. Except for a small group of exotic words, that in a publicistic text serve for a recipient as indicators of a foreign culture, modern loan words (names of people) have a nominative function, characterizing a person by their activities, and an expressive one, characterizing a person by their behavioural peculiarities and views.
\end{abstract}

Key words: loan words, neologisms, mass media language.

Надійшла до редакиії 26.09.2019 p.

УДК [811.161+811.163]'371'373.42-115:35.077.535.6

DOI: https://doi.org/10.18524/2413-0613.2019.23.183122

О. М. Новак

кандидат філологічних наук,

доцент кафедри загального та слов'янського мовознавства

філологічного факультету

Одеського національного університету ім. І. І. Мечникова,

Французький бульвар 24/26, м. Одеса, 65082, Україна,

movoznavstvo98@gmail.com

\section{СЕМАНТИЧНА СТРУКТУРА ЛЕКСЕМ-КОГНАТІВ ВОЛЯ / ВОЉА В УКРАЇНСЬКІЙ ТА СЕРБСЬКІЙ МОВАХ}

У статті представлений аналіз структури та обсягу значення лексеми „воля” в українській та сербській мовах в семасіологічному та перекладацькому аспектах. Об'єктом дослідження є когнати воля / воља. Предметом дослідження обрано семантичний обсяг лексем 3 коренем вол'-. Мета дослідження полягала у порівняльному аналізі структури та обсягу значення лексеми воля / воља та похідних від неї в українській та сербській мовах. Дослідженню підлягали різнорівневі мовні одиниці та явища, що пов'язані з лексикою, словотвором, фразеологією слов'янських мов, а також культурна конотація досліджуваних одиниць. Як матеріал дослідження використовувалися дані тлумачних та етимологічних словників.

Висновки: здійснивши порівняльний аналіз семантичного обсягу когнату 'воля', ми виявили, що етимологічно тотожні слова 3 коренем вол'- в сучасних українській і сербській мовах мають різний семантичний і дериваційний потенціал, а також різні значення, що сформувалися в результаті дивергенції семантичної структури. Такі лексеми складають корпус міжмовних омонімів і паронімів, мають різну семантичну та стилістичну сполучуваність, а також різне конотативне значення. Хибні друзі перекладача - похідні лексеми з коренем вол- вимагають особливої уваги при навчанні слов'янських мов як іноземних. Практичне застосування результатів дослідження пов'язане з можливістю їх використання у практиці викладання сербської та інших слов'янських мов як іноземних в інослов'янскому оточенні та при перекладі. 
Ключові слова: когнати, міжмовні омоніми, семантичний обсяг, українська мова, сербська мова.

Розбіжності у семантичному розвитку етимологічно тотожних слів у споріднених мовах активно досліджуються в сучасній порівняльній семасіології, проте остаточної термінологізації цього явища у славістиці поки що немає. Поняття когнат (лат. cognati букв. “споріднені”) спочатку було термінологізоване у західноєвропейській лінгвістиці, цей термін ще не увійшов до українських словників лінгвістичної термінології, проте вживається у науковій літературі. Досліджуючи міжмовні лексичні паралелі, що утворилися шляхом дивергенції семантики етимологічно тотожних одиниць, ми обираємо робочу дефініцію, запропоновану В. В. Акуленком: „когнатыл - слова общего происхождения, восходящие к одной и той же праформе в языке-основе” [1, c. 112]. Семантична структура когнатів зазвичай широко варіюється, тому когнати поділяються на повні (досить рідкісне мовне явище) і часткові, що репрезентують різні види семантичних зрушень. В сучасних слов'янських мовах маємо близько двох тисяч слів загальнослов'янського походження, проте не всі вони мають однакове значення. В наших попередніх роботах ми вже порівнювали семантичну структуру, обсяг значення і словотвірний потенціал деяких спільнослов'янських слів, що мають аксіологічну значущість (,цүінність" [7] і ,краса / лепота" [6]). Предметом дослідження цієї роботи обрано семантичний розвиток слов'янського когнату *volja в українській i сербській мовах.

Джерелами фактичного матеріалу слугували тлумачні словники української та сербської мови (Словник української мови в 11 т., Речник српскохрватског кюижевног језика Матицее Српске), етимологічні та фразеологічні словники української та сербської мов (Старослов'янський словник по рукописам X-XI cm.) та ін.

Лексема *volja є одиницею спільнослов'янського лексичного фонду та одним iз найдавніших праслов’янських запозичень. Етимологічно *volja сягає ще періоду праіндоєвропейської єдності. Ще А. Мейє зазначав, що значення 
індоєвропейського слова складне, а структурні одиниці - морфеми - виражають різноманітні граматичні відношення й узагальнюють складні психічні процеси, що відбуваються у свідомості носіїв мови [5, с. 170]. Дослідник стверджував, що “морфологічні елементи, на які ми розкладаємо індоєвропейське слово, не $\epsilon$ абстракціями граматиків: це символи, за допомогою яких виражено системи асоціацій, спільних для всіх осіб того самого мовного коллективу” [5, с. 169]. Власне, йдеться про те, що морфологічні елементи в похідних словах певним чином віддзеркалюють відповідну мовну картину світу.

В етимологічному словнику М. Фасмера знаходимо таку довідку: „во́ля укр. во́ля, др.-русск., ст.-слав. вольн $\theta \dot{\varepsilon} \eta \mu \alpha, \quad \gamma \nu \omega ́ \mu \eta$ (Клоц., Супр.), болг. воля, сербохорв. воља, словен. vólja, чеш. vule, слвц. vol'a, польск. wola, др.-польск. wol, в.-луж., н.-луж. Wola. Связано чередованием гласных с велеть, довлеть. Родственно лит. vali „воля”, лтш. vala „сила, власть”, др.-исл. val (ср. р.), д.-в.-н. wala (ж. р.) „выбор”, нов.-в.-н. Wahl - то же, wollen „хотеть”, др.-инд. v́ras „желание, выбор”, авест. vāra- „воля, отбор”, кимр. guell „лучше” [12, т. 1, с. 67]. Як бачимо, лексема воля є етимологічно пов'язаною з дієсловом *velëti та здавна має відтінок процесуальності (на відміну, наприклад, від слова свобода) та семи 'бажання', 'влада', 'сила', 'вибір / відбір / можливість обрати'. 3 такою полісемантичною структурою ця лексема зафіксована й у старослов'янських рукописах [11, с. 120, 121].

У словнику-довіднику В. Жайворонка „Знаки української етнокультури” зазначається, що слово-концепт ВОЛЯ в українській мові має значення „свобода, незалежність на противагу неволі, рабству; також в особистому плані - здатність здійснювати, переходити від думки до дії; у народі символізує силу; ставиться понад життя; часто зіставляється 3 долею, узалежнюється від неї” [3, c. 113]. В сучасній українській літературній мові ця лексема функціонує у таких лексико-семантичних варіантах: воля „1. одна з функцій людської психіки, яка полягає насамперед у владі над собою, керуванні своїми діями й свідомому регулюванні власної поведінки; прагнення досягти своєї мети; 2. бажання, 
хотіння, вимога, наказ; 3. право розпоряджатися на свій розсуд; влада; дозвіл, згода, рішення; 4. відсутність обмежень; привілля; особисте життя вдома; 5. свобода, незалежність; 6. звільнення селян від кріпацтва" [10, т. 1, с. 153]. Як бачимо, в українській мові перше значення позначає функцію психіки, що може свідомо керувати своїми вчинками, тобто 'воля' знаходиться на перетині понять 'бажання' й 'свідомий вибір', оскільки передбачає інтелектуальну, емоційну, фізичну активність і зовнішній прояв.

У лексикографічних джерелах української мови зафіксовано наступні ідіоми: волю вволити чиюсь „виконати чиєсь бажання, послухати когось”; вольному воля „як хочете (хочеш)”; воля ваша (твоя) „уживається для шанобливого висловлення згоди з ким-небудь; хай буде так”; дати волю „не обмежувати у діях, вчинках і т. ін; не стримувати себе в чому-небудь"; дати волю ногам „тікати, швидко бігти, уникаючи якоїсь небезпеки; завзято, запально танцювати”; дати волю рукам „битися; хапати, обіймати когонебудь”; дати волю серию „дозволяти собі розчулюватися, віддаватися своїм почуттям; не стримувати свого гніву; обурюватися"; дати волю сльозам „нестримно, невтішно, гірко плакати; ридати”; дати волю язикові „не стримуватися, не контролювати себе у висловах; дозволяти собі говорити зайве”; не мати [своєі] волі (сили волі) ,легко піддаватися різним впливам; бути нестійким, нерішучим, безвольним”; пустити на волю Божу „не затримувати кого-небудь, відпускати”; диктувати свою волю „нав'язувати кому-небудь свої погляди і змушувати його діяти відповідно до них”; люди доброї волі „ті, що бажають народові добра, миру”; остання воля „бажання, розпорядження, висловлене перед смертю; заповіт"; по [свой $і$ т.ін.] волі „як хто хоче (хотів), за своїм уподобанням; за власним, бажанням, без примусу"; по волі чи по неволі „так чи інакше; все одно”; віддаватися (віддатися) на волю „давати можливість розпоряджатися собою”; мати волю над ким-, чим-небудь „вільно ким-небудь розпоряджатися; впливати на когось”; своя воля „хтось має право робити що-небудь на свій розсуд”. 
Цікаве комплексне дослідження словотвірного гнізда із вершиною вол'в українській мові здійснила О. В. Ляхова [4]. 3 метою встановлення семантичного обсягу концепту ВОЛЯ дослідниця розглянула семантичні i дериваційні відношення між компонентами словотвірного гнізда і дійшла висновку, що деривати другого ступеня похідності вільний (як і похідний від нього прислівник вільно) пов'язуються 3 вільною особистістю і концептом „незалежність”, тобто „семантичний компонент „бажання” втілюється в домінуючому словниковому значенні слова воля, пов'язаному з бажанням діяти на власний розсуд” [4, с. 127].

Поліфункціональною, полісемантичною та частотною є лексема воља в сучасній сербській мові. Академічний словник (Речник српскохрватског къижевног језика. Матища Српска) фіксує 3 значення, в яких виокремлюються додаткові семантичні варіанти. Наведемо їх: 1. способност човечјег духа која се испољава у свесном доношењу одлука и свесном поступању, деловању; стање свести усмерено на смишљено деловање, стварање и извршавање одлуке: чврста воља, слободна воља, слаба воља, јака воља; 2. а. жеља и свесна тежња за остварењем неке намере, жеље, хтење; решеност, одлучност у извршењу те намере, жеље; готовост, спремност: немати воље да се нешто учини, радити без воље; б. прохтев, жеља: немати воље за јело; в. одлука, заповест; право и могућност заповедања, господарења : спровести иареву вољу, вољу закона; г. прихватање нечије жеље, пристанак, сагласност: преместити некога без негове воље, удати се мајчином вољом; 3. душевно стање, расположење: бити добре (веселе) воље, бити лоше (зле) воље [9, с. 165]. Як видно з наведених зі словника даних, у сербській мові існує доволі широкий спектр значень лексеми вољ $a$, наявні семи 'здатність свідомо прийняти рішення', 'продукування та виконання рішень', ‘бажання’, ‘прагнення', 'рішучість у виконанні наміру', 'рішення, наказ', 'право і можливість керувати кимось', а також специфічне для цієї спільнослов'янської лексеми значення 'психічний стан, настрій'. 
На відміну від української, в сербскій мові значення слова воља 'душевно слагање или расположење у коме се неко налази' $\epsilon$ дуже поширеним, продуктивним, найчастотнішим в ідіомах 3 цим компонентом, наприклад: Човек добре воле (укр. „людина у доброму настрої, у гуморі, у позитивному регістрі”); Он е данас зле воле (укр. „у нього сьогодні поганий настрій, він не в гуморі").

У словнику Дж. Оташевича (Фразеолошки речник српског језика) зафіксовані такі ідіоми: бити широке воље „бити добро расположен”; до миле вољ $а$ „колико и како се хоће, неограниченно”; доћи до воља и главе „претерати, превршити сваку меру”; за вољу или за невољу „милом или силом”; изаћи некоме из воље „изгубити нечију наклоност, нечије симпатије”; имати злу вољу „бити непријателски расположен”; преко воље „нерадо, супротно од властите жеље”; пустити сриу на вољу „не ограничавати своје жеље”; пустити некоме на вољу „допустити некоме да ради по жељи, по свом нахођењу, не ограничавајући га, не контролишући га”; ући некоме у вољу „допасти се, свидети се некоме" [8, с. 27].

Праслов'янське значення дієслова ВОЛИТИ „бажати” в сербській мові розширилося, позначає не тільки „бажати”, а й „любити, кохати, подобатися”: Волио бих да идем у Париз, допада ми се (укр. „я б хотів поїхати у Париж, він мені подобається”), Волим класичну музику (укр. „мені подобається класична музика / я люблю класичну музику”), але й волим те (укр. „я тебе кохаю”). Відсутність у структурі семантичного значення українських лексем 3 коренем -вол'- сем 'приємній емоційний стан', ‘душевна гармонія', ‘добрий настрій', 'симпатія', 'кохання' та ін. стає причиною численних помилок у перекладі, коли втрачається не тільки емоційний, конотативний елемент, але й подекуди основний зміст висловлювання. Такі лексеми мають спільнослов'янське походження, але різне семантичне значення, безперечно, потрапляють у клас „хибних друзів перекладача”. 
Лексичні розбіжності зазначаємо й у похідних лексемах, що функціонують як міжмовні омоніми в українській і сербській мовах: наприклад, сербськ. вољно (укр. свідомо, добровільно), вољност (укр. бажання, готовність щзось робити), безвољни (укр. у поганому настрої), повољан (укр. сприятливий, відповідний, той, щзо повністю підходить), вољак (укр. приємна людина) тощо. В сербській мові лексема невоља багатозначна, означає „неможливість здійснити бажане: неприємна, несприйнятлива ситуація, біда, скрутні обставини, нещастя”; відповідно невољник, невољница означають „бідолаха, нещасна людина, яку можна пожаліти” і не є синонімами до слова раб.

Слов'янські когнати, що позначають базові аксіологічні поняття, можуть суттєво розрізнятися за семантичною структурою, переходять в клас міжмовних омонімів. Тому вважаємо, що вивчення усього комплексу значень, сполучуваності, конотаційного складника семантики $\epsilon$ перспективним у подальших дослідженнях і необхідним при викладанні сербської як іноземної в інослов'янському середовищі та у практиці перекладу.

\section{Список використаних джерел та літератури}

1. Акуленко В. В. Вопросы интернационализации словарного состава языка. Харьков : Изд-во Харьк. ун-та, 1992. 213 с.

2. Етимологічний словник української мови : у 7 т. / гол. ред. О. С. Мельничук. К. : Наук. думка, 1982-2006.

3. Жайворонок В. Знаки української етнокультури : Словник-довідник. К. : Довіра, 2006. 703 с.

4. Ляхова О. Словотвірний аспект в аналізі концепту ВОЛЯ. Вісник Харківського нац. ун-ту імені В. Н. Каразіна. Серія “Філологія” (74). С. 124-129.

5. Мейе А. Введение в сравнительное изучение индоевропейских языков. М.; Л.: Гос. соц.экон. изд-во, 1938. 512 с.

6. Новак О. Н. Аксионим лепота в сербской лингвокультуре // Мова. Одеса: Астропринт, 2016. № 26. C. $47-51$.

7. Новак О.Н. Анализ семантического объёма лексем ценность / вредность в русском и сербском языках // Мова. Одеса: Астропринт, 2017. № 28. С. 98-102. $1045 \mathrm{c}$.

8. Оташевић Ђ. Фразеолошки речник српског језика. Око 25000 чл. Нови Сад : Прометеј, 2012.

9. Речник српскохрватског књижевног језика. Матица Српска: в 6 т. / [ур. одбор М. Стевановић и др.]. Нови Сад-Загреб, 1967-1976. 1980.

10.Словник української мови : в 11 т. / АН УРСР. Ін-т мовознавства; ред. І. К. Білодід. К., 1970-

11.Старославянский словарь (по рукописям X-XI веков) / ред. Р. М. Цейтлин, Р. Вечерка, Э. Благова. М.: Рус. яз., 1994. 842 с.

12. Фасмер М. Этимологический словарь русского языка. В 4-х т. / пер. с нем. и доп. О. Н. Трубачев. М.: Прогресс, 1986. T. I-IV. 


\title{
Referenses
}

1. Akulenko V. V. Voprosy internatsionalizatsii slovarnogo sostava yazyka. Khar'kov : Izd-vo Khar'k. un-ta, 1992. $213 \mathrm{p}$.

2. Etymolohichnyy slovnyk ukrayins'koyi movy : u 7 t. / hol. red. O. S. Mel'nychuk. K.: Nauk. dumka, 1982-2006.

3. Zhayvoronok V. Znaky ukrayins'koyi etnokul'tury : Slovnyk-dovidnyk. K. : Dovira, 2006. 703 p.

4. Lyakhova O. Slovotvirnyy aspekt v analizi kontseptu VOLYa. Visnyk Kharkivs'koho nats. un-tu imeni V. N. Karazina. Seriya "Filolohiya" (74). P. 124-129.

5. Meye A. Vvedenie v sravnitel'noe izuchenie indoevropeyskikh yazykov. M.; L.: Gos. sots.-ekon. izd-vo, 1938. $512 \mathrm{p}$. P. 47-51.

6. Novak O. N. Aksionim lepota v serbskoy lingvokul'ture // Mova. Odesa: Astroprint, 2016. № 26.

7. Novak O. N. Analiz semanticheskogo ob'ema leksem tsennost' / vrednost'v russkom i serbskom yazykakh // Mova. Odesa: Astroprynt, 2017. № 28. P. 98-102.

8. Otashevyћ Ђ. Frazeoloshky rechnyk srpskoh jezyka. Oko 25000 chl. Novy Sad : Prometej, 2012. $1045 \mathrm{p}$.

9. Rechnyk srpskokhrvatskoh kњyzhevnoh jezyka. Matytsa Srpska : v 6 t. / [ur. odbor M. Stevanovyћ y dr.]. Novy Sad-Zahreb, 1967-1976.

10. Slovnyk ukrayins'koyi movy : v 11 t. / AN URSR. In-t movoznavstva; red. I. K. Bilodid. Kyyiv, 1970-1980.

11. Staroslavyanskiy slovar' (po rukopisyam X-XI vekov) / red. R. M. Tseytlin, R. Vecherka, E. Blagova. M.: Rus. yaz., 1994. 842 p.

12. Fasmer M. Etimologicheskiy slovar' russkogo yazyka. V 4 t. / per. s nem. i dop. O. N. Trubachev. M.: Progress, 1986. T. I-IV.

\section{O. M. Novak,}

Candidate of Philology,

Associate Professor of General and Slavic Linguistics Department

Odesa I. I. Mechnikov National University,

24 / 26, Frantsuzky Blvd., Odesa, 65058, Ukraine,

olganovak2@gmail.com

\section{SEMANTIC STRUCTURE OF LEXEMES ВОЛЯ / ВОљ $A$ IN UKRAINIAN AND SERBIAN LANGUAGES}

\begin{abstract}
Summary
The article presents an analysis of the structure and semantic volume of the meaning of the word воля/ воља "will" in the Ukrainian and Serbian languages in axiological and interpreting aspects. The object of the study are cognates "воля / воља" in the Ukrainian and Serbian languages. The subject of the research is the semantic volume of the lexemes "воля / воља" in the Ukrainian and Serbian languages. The purpose of the study is to analyze the structure and the volume of meaning in the axiological and interpreting aspects. Multilevel linguistic units and phenomena associated with the vocabulary, word formation, phraseology of the Serbian and Ukrainian languages and cultural connotation of the mentioned
\end{abstract}


units were investigated. The data from a thesaurus, an etymology dictionary, a dictionary of associations were analysed in the research.

Finding of the research: having conducted a comparative analysis of the semantic volume of the lexemes воля / воља "will" in Slavic languages, we found out that the examined lexemes are not complete equivalents and have different semantic and derivational potential. The practical value of the research is to use its results to optimize the processes of teaching Serbian as a foreign language.

Key words: cognates, interlanguage homonyms, semantic volume, Ukrainian language, Serbian language.

Надійшла до редакиї 21.09.2019 p.

УДК 811.162.1'373.611:001.4”1500/1939”

DOI: https://doi.org/10.18524/2413-0613.2019.23.183123

B. В. Тожиєва,

здобувач кафедри загального та слов'янського мовознавства

філологічного факультету

Одеського національного університету імені I. I. Мечникова

Французький бульвар, 24 / 26, м. Одеса, 65058, Україна,

vitalina.gubich@gmail.com

\section{АФІКСАЦІЯ ЯК СПОСІБ ТЕРМІНОТВОРЕННЯ МЕТАМОВИ ЛІНГВІСТИКИ В СЕРЕДНЬОПОЛЬСЬКУ ТА НОВОПОЛЬСЬКУ ДОБУ}

Статтю присвячено розгляду афіксального способу творення лінгвістичної термінології польської мови протягом XVI ст.-1939 р. Продуктивним різновидом афіксального термінотворення була суфіксація, представлена різними формантами. Префіксацією та конфіксацією утворено незначну кількість спеціальних лексем, проте останні набули поширення в новопольську добу, що пояснюється розвитком і поглибленням лінгвістичних знань. Афіксація відіграла вагому роль на етапі становлення лінгвістичної термінології, сприяла заміні описових конструкцій однослівними номінаціями, які відповідали вимогам системності, точності, стислості, що належать до рекомендованих засад у сучасному термінотворенні.

Ключові слова: лінгвістична термінологія, спосіб термінотворення, афіксація, префіксація, суфіксація, конфіксація, польська мова.

Специфіка термінологічної номінації полягає в створенні найменувань особливого типу - термінів. Основні їі принципи повністю відповідають мовній номінації [3, с. 25]. „Номінація (від лат. nominatio „називання, іменування”) є центральним поняттям ономасіології, одного 3 двох взаємодоповнювальних аспектів семантики як науки (поряд iз семасіологією)" [УМЕ, с. 437]. Особливості та способи термінономінацій розглядали О. Войцева [2], В. Даниленко [6], С. Гриньов-Гриневич [4], І. Кочан [9]. Лінгвістичній термінології різних мов присвячено наукові розвідки А. Багмут [1], П. Гриценка [5], 3. Свлоєвої [7], В. Захарчин [8], І. Казимирової [5], А. Корончевського [15] та ін. Проте вивчення лінгвістичної термінології (далі - ЛТ) польської мови в 